\title{
Managing Love and Death at the Zoo: The Biopolitics of Endangered Species Preservation
}

\author{
Matthew Chrulew
}

The 24 May 1968 issue of Time magazine featured a short article with the title 'Animal Behavior: Love at the Zoo'. Its topic was the breeding of animals in zoological gardens, but unlike the puff pieces featuring neonate mammals routinely fed to media by zoo publicity departments today, this story sought to highlight the unique dilemmas encountered on the way to such happy successes. It may not have broached the precise mechanics of rhino husbandry or the numbers of elephant miscarriages, but it did recount the frustrations of managing reproduction in these peculiar institutions, from storks, emus and tortoises attempting to mate with their caretakers, to the dangers of provoking a lion's jealousy. Zoos' insistence on absolute visibility has often revealed elements of animal sexuality disruptive of their bourgeois tranquillity, but these even more unseemly behind-the-scenes anecdotes, from the 'embarrassing' to the 'pathetic', expose the extent to which, behind their facade of naturalism, zoological gardens control all aspects of animal life, not only diet and habitat but even the tawdry details of procreation divulged here with such obvious delight.

Given this situation of utter dominance, we can hardly take the article's closing advice to zookeepers with anything but irony. To prevent from being harmed by 'impudent' captives, it is suggested that one 'assume a super-alpha status' - a position of ultra-authority naturalised as an extension of animals' innate need for hierarchy. Of course, attacks by animals potentially expose zoo workers and overeager visitors to grave injury, but such acts (just like refusal to breed) are the last form of resistance available to a caste of creatures entirely at the whim of their kindly protectors, sheltered in artificial, regimented enclosures, whose emblematic behaviour was for a long time the stereotyped pacing of a neurotic. In our historical moment of planetary imperialism, mass extinctions and anthropogenic climate change, the natural world is said to have been 'completely absorb[ed]' by a rationalising culture (Adorno 115). Zoological gardens, where living animals are displayed for the edification of human visitors, are for many the very epitome of this process, the animals within a 'living monument to their own disappearance' (Berger 24). It is safe to say that 'super-alpha status' has long since been assumed-and achieved. 
The reported insights into 'biological befuddlement' had been presented at an American ethology symposium by Swiss professor and zoo director Heini Hediger, who was a central figure in the science and technique of zoo biology. From the mid twentieth century, his writings such as Wild Animals in Captivity, as well as practical interventions like his operational review of Sydney's Taronga Zoo, were foundational for the biopolitical reforms at the basis of modern methods of welfare-centred zookeeping (Hediger, Wild; Hediger, Report). Responding to the problems of high mortality rates, failure to breed, and repetitive, stressed behaviour, on the basis of long-term, speciesspecific observation and experimentation, Hediger set down guidelines for the production of healthy, happy animals willing to mate and display natural behaviours, and thereby laid the groundwork for contemporary zoo biology and such practices as animal training, environmental enrichment and captive breeding. Since that time, as the exchange of wild animals became increasingly regulated, zoos have reinvented themselves as wildlife parks devoted to the preservation of endangered species. Amid the crisis of widespread and relentless habitat loss and species extinction - processes in which they were historically implicated — zoos became defined as salvific arks, bearing life's remnant and our hopes for redemption. Building on techniques such as Hediger's, the goal of conserving threatened wildlife populations could be pursued by a benevolent regime of scientific management within their curiously well-ordered microcosms of nature.

'Love at the Zoo': the Time article's subtitle pithily captures the nature and stakes of contemporary zoo biopolitics. In the context of these 'unproductive infatuations', the term presents as an absurd anthropomorphism, given that, in the spectacle of enforced animal breeding and its comedic side-effects, we witness the bestialised underside of our own notion of romantic love based on free choice and culturally distanced from the directives of instinct. But this administration of zoo-love is motivated by our own purported love for the animals: a love that seeks to maintain healthy and happy wild-seeming exhibits, and a love that seeks to rescue species judged in danger of extinction. Unfortunately, our attempts to put this love into practice are too often misdirected, if not badly botched. Perhaps there is even a surplus of love, and attention to it, circulating in these over-involved institutions. At least, we should hardly be surprised at the occasional disobedience of those smothered by this caring attention, or the refusal - and confusion - of those expected to perform 'love' for the good of their species.

In a collection that explores the fate of unloved creatures in this time of extinction, this essay will attend to those subjected to too much love: animals whose membership of an endangered species singles them out for intense intercession on the part of concerned scientists. Such is the principal achievement of Michel 
Foucault's work: to problematise not only the negative operations of power - acts of violence by which the weak are repressed or excluded, made invisible-but also power in its productivity, where new internal domains of intervention are opened up to classification and government, to inescapable visibility. Under the rubric of Foucault's notion of biopolitics - which signifies the problematisation of life itself as an object of political power, but has rarely been considered as it relates to nonhuman animal life-I will illustrate the operation of endangered species preservation in twentieth and twenty-first century zoological gardens. The intensive care exercised by these stewards is not always successful; in its focus on the anatomical or genetic species body at the expense of emplaced creatures, the zoo produces not full, flourishing lives but a wounded life, robbed of vital connectivities and expressions. It has its dark underbelly, too, such as when the unloved surplus of breeding programmes are quietly euthanised for reasons of (un)utility. Though the zoo tries to keep it hidden, this regime devoted to the fostering of life at the same time produces damage and death. This caesura between the overloved and the unloved, between the politics of life and death, bios and thanatos, brings into stark relief one of the central ethical questions of our time: how should we love in a time of extinction?

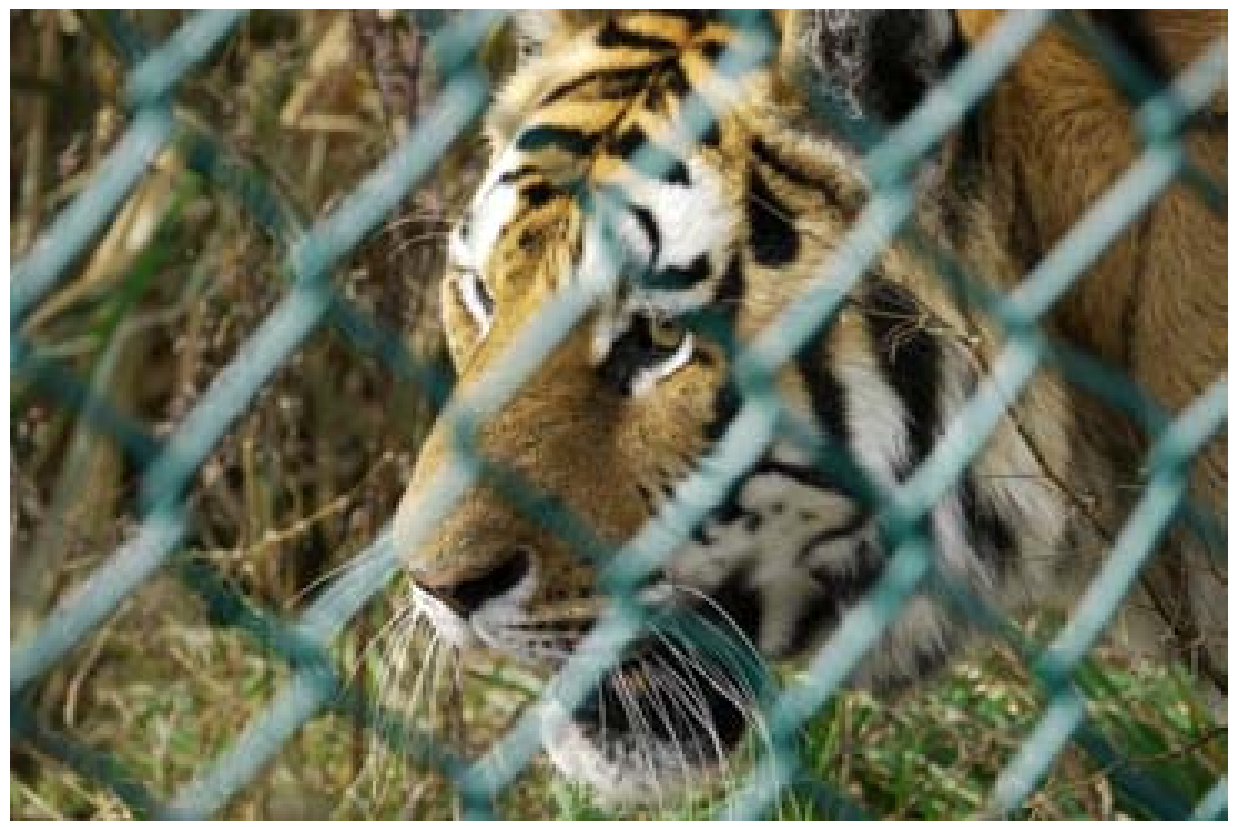

A Siberian Tiger (Panthera tigris altaica) behind bars.

Image by Ken Snider, used under a CC BY-SA 2.0 licence 
This work continues the broader project of a genealogy of zoological gardens, one that understands zoos as heterotopias within networks of wildlife that are structured by productive relations of power (Chrulew). My goal is to examine the techniques of power through which exotic and native animals have been captured and kept, ordered and displayed, bred and tested, archived and conserved, saved and revealed - that is, the various ways they have been acted upon and 'made to speak'.

One of the central concepts of Foucault's analysis of power in modernity was that of biopolitics, which he defined in The Will to Knowledge as a form of power over life that

focused on the species body, the body imbued with the mechanics of life and serving as the basis of the biological processes: propagation, births and mortality, the level of health, life expectancy and longevity, with all the conditions that can cause these to vary. Their supervision was effected through an entire series of interventions and regulatory controls: a biopolitics of the population. (139)

This concept has come to play a significant role in the work of Giorgio Agamben, Michael Hardt and Antonio Negri, Roberto Esposito, and others. The contemporary debates have concentrated on questions of global politics in late capitalism, and the way in which the biopolitical capture of life has been so entwined with the domination and putting-to-death of excluded (human) subjects. But except on the margins of this discourse, there has been little recognition that we must also consider how nonhuman animal life is caught up in apparatuses of biopower: from the management of wilderness reserves, to industrial food production, to the monitoring and culling of feral urban populations, to our relationships with pets and companion species, to the projects, in which zoological gardens participate, of endangered species preservation. ${ }^{1}$

What this work helps to make clear is the ambiguous nature of this conservationist biopolitics in zoos. Much of the debate has centred on the nature of the link between the affirmation of life and the production of death. For Foucault, biopolitics is a fundamentally productive mode of power, which does not mean that it is always good, as it is indeed quite often dangerous, but instead that its goal is always the fostering of life: while traditional sovereign power, he argued, was the explicitly violent power to let live or make die, the quieter function of

\footnotetext{
1 Recent examples of important work in this direction include Shukin, who traces the 'rendering' of animals within circuits of capital, and Haraway, Species, who describes the enmeshed lives of companion species as 'significant others'. While Haraway is overtly suspicious of 'the apparatus of apocalyptic wildlife biology' (145), her pages on endangered species conservation (145-50) only outline the complicating effect of biodiversity discourse on practices of dog-breeding.
} 
biopower is instead to make live or let die. Nonetheless, he recognised that it has historically become intertwined with such exclusionary logics as biological racism (Foucault, Society 239-263). Agamben, by contrast, argues that biopower is in its very nature exclusionary: insofar as it makes a distinction between bios and $z o \bar{e}$, between human political life and the mere life of organisms, it is set up so as to produce bare life, which is life excluded from the polis, life that can be killed without it being murder (Homo Sacer). His examples run from refugees, to medical cases such as 'overcomatose' patients, to the Muselmänner of Nazi death camps, to nonhuman animals (The Open). Without needing here to adjudicate this debate (for further discussion, see, for example, Ojakangas; Rose, Politics), it is important to register its central problem: how is it that societies so devoted to the task of making live - to flourishing populations, healthy bodies, extended lifespans - have been capable of such unprecedented violence?

For all their disagreements, each of these thinkers offers their analysis of biopolitics as a diagnosis of the operation of power today, in order that it can be contested in its intolerable effects. This critical attitude is too often lacking when it comes to the beneficent and salvific aura of conservation and other prevailing regimes of scientific knowledge of animals. Insofar as these saviour savoirs also exert influence over the actions and lives of animals, they must be assessed as apparatuses of power. It is of course essential that we attempt to combat the anthropogenic extinction and mass killing of nonhuman species, but the ways in which we might do so are neither easy nor self-evident. As Timothy W. Luke has shown so well, ecological discourses must themselves be subjected to 'ecocritiques' that question their problematic elements - whether nostalgic, technicist or otherwise - towards more just and effective proposals and interventions. Our love for nature is too easily botched not to recognise its infinite demands. The task remains to examine the biopolitics of endangered species preservation as a form of power/knowledge devoted to making animals live, but nonetheless perilously bound up in the production of impairment and death.

Zoos were of course from the first bound up with killing and loss on an enormous scale. The accumulation of animals through colonial systems of extraction had devastating impacts on habitats and life-worlds. Often, numerous animals were slaughtered in the collection of a few, mothers killed so their infants could be captured. Vulgar means of transport and enclosure meant massive death rates: often few survived the journey, or lasted long in their new 'homes'. The prevalence of species-thinking, in which each individual is only perceived as a token of its inexhaustible taxonomic type, made such losses acceptable - as each animal was in principle replaceable. Thus every zoo 'specimen' that was viewed by the metropolitan masses trailed innumerable extinguished lives and 
other forms of harm and disturbance to the composition of generations and ecologies. In order to present living examples of nature's wonder to the eyes of the zoo visitor, nature itself was wounded. All zoo exhibits are haunted by this yet unextinguished legacy of violence (see, for example, Rothfels 44-80).

However, even to focus, as the zoo would prefer, only on those individual animals whose flesh-and-blood presence enlivens its gardens, does not leave us with 'nature' perfectly captured and portrayed. Rather, surviving animals endured captivity as the living dead. As the following pair of nineteenthcentury critiques illustrate, zoos have long been perceived as damaging to life. The first from 1888:

To call the taming of an animal its 'improvement' is in our ears almost a joke. Whoever knows what goes on in menageries is doubtful whether the beasts in them are 'improved'. They are weakened, they are made less harmful, they become sickly beasts through the depressive emotion of fear, through pain, through injuries, through hunger. (Nietzsche 66-7)

The author of these lines is Friedrich Nietzsche, in the last year of his sane life, writing in Twilight of the Idols of the so-called 'improvement' of man, but as always with a keen sense of the bodily urges and perils of material life, including that of animals. Nietzsche articulates what the entire effort of zoos is now directed towards repairing: the wounding brought about by captivity. Another critique from only five years earlier, concerned with accurate knowledge, asserts the dubious scientific value of observing animals in zoos, a result of the powereffects that strip them of their form of life:

I have passed days and weeks by many a lion's cage in European and American gardens, intent upon study and observation; but with the exception of having, by numerous sketches, impressed upon my mind the anatomical peculiarities of these interesting animals, I cannot say that in other respects my perserverance has been rewarded to any great extent. I have simply found that an animal, as closely confined as most of them are in zoölogical gardens, retains none of its natural habits; it only exists - a mere automaton; and even this existence is seemingly under protest. (Link 1226)

This familiar image of a denatured, exposed animal reduced to naked subsistence can be clearly read in terms of Agamben's conception of biopolitics, in which the separation of bios and $z o \bar{e}$ creates a space for 'bare life' (Homo Sacer). As Agamben argues in The Open, animals are the originary targets of this perilous political decision; and the nineteenth-century zoological garden can be seen as a site, analogous to the camp, that produced barely living animals reduced to 'automatons' in their stereotyped pacing and environmental captivation, 
their very instincts cancelled by confinement. They survived, without truly living - and bore witness, in their silence, to the death that surrounded them. Insofar as zoological thinking does not recognise animals' forms of life, but only their visible forms - the mere life of their observable anatomical species traitstheir isolation in captivity, away from their relational bios amid habitat and kin, produces a weakened, sickly, bare life. Zoo-logic injures the living.

However, in the second half of the twentieth century, zoos were swept up in a constant process of reform that understood the role of the institution to be the thriving of its captive animals, a goal to be achieved through applying the principles of biological and ethological science. Such conditions as described by Nietzsche and the naturalist Link were not in the best interests of zoos, either economically (in terms of animal longevity, disease and death) or when it came to the niceties of public display. Nor were they the limits of afflictions; as one history puts it, 'To stereotyped movement the list of pathologies observed in captive animals adds sexual disorders, auto-aggression and auto-mutilation, and consumption of faeces and the paintwork of cages, most of which make it impossible to exhibit the animals' (Baratay and Hardouin-Fugier 276). It was in response to such problems that a biological basis for animal keeping was developed. Led by Hediger, this produced a form of biopower more in line not with Agamben's but with Foucault's original, somewhat different conception: that is, a productive power devoted to the nurture of life.

Histories of zoos customarily describe the 'Hagenbeck revolution' that transformed zoo architectural design from pits and fences to hills and moats, fabricating exhibits as landscape and habitat and making possible their now customary Edenic naturalism. ${ }^{2}$ But if we are to avoid privileging human spectatorship at the expense of the effects of power on animal bodies, it is important also to foreground the Hediger revolution in practical zookeeping which painstakingly elaborated procedures of 'biologically appropriate' care in feeding regimens, breeding practices, behavioural interventions and other elements of zookeeping protocol. In Hediger's work, concepts like 'territories' and 'zones', 'flight distance' and 'critical distance' were used to refine architectural designs and management practices, relating cage types and sizes to species' typical behaviours. Enclosures were thus not only aesthetically organised for the benefit of spectators, but strategically constructed so as most effectively to contain their interns. Zoos went from rather crude confinement and subsistence to a detailed, precise, scientific apparatus that took as its goal to 'make live', devoting itself to the health and hygiene, nurture, growth and flourishing of living organisms (Gruffudd), grasped through the 'population' as object of both knowledge and power. This biopower complemented the disciplinary strategies of separation, seeking to adapt animals to the conditions of captivity. Scientific

2 The best history of Hagenbeck's role as animal trader and zoo showman is Rothfels. 
discourses of zoo biology, ethology and animal psychology accumulated statistics and reports that reflected, and in turn modified, the zoo's circumstances of corporeal influence. The knowledge produced was reliant on, and also fed back into, the practices of animal keeping, that is, the power regime of confinement, discipline, and biopower impacting on animal bodies and 'souls'.

The post-war practices of biologically productive zookeeping are instances of the emergence within human-animal relations of what Foucault described in The Will to Knowledge as the twin poles of the biopolitics of the population and the anatomo-politics of the body. Scientifically-based care took upon itself the negative task of reducing the anthropogenic effects of captivity decried by Nietzsche and Link, 'to neutralise as far as possible all modifying (nonhereditary, externally conditioned) and mutative (hereditary) changes and degeneration phenomena' (Hediger, Wild 40), and ultimately the positive task of producing normal, 'species-typical' behaviour through 'environmental enrichment'. In this regime of truth, the effects of human contact were defined as 'abnormal', and wild nature was the norm to be produced (if also, in its security and comfort, 'improved') by a thorough, self-concealing apparatus of power. Donahue and Trump describe how because

regulatory agencies often lacked the technical expertise to evaluate the health or welfare of exotic animals, zoos shaped a significant number of the rules under which they now operate. Essentially, zoos' economic interest in keeping animals alive and healthy made them experts in the capture, transportation, feeding, housing, and veterinary treatment of exotic species. To stay in business, zoos had to ensure the very animal welfare that, at times, their critics accused them of neglecting. (89)

Indeed critics of zoos accepted this biopolitics as the terms of their opposition: they 'monitored living conditions ... but without questioning the principle of captivity', pointing out 'insufficient care, dirty enclosures, confined animals, brutal keepers and tiny cages', as well as 'overpopulation, unsuitable conditions, groupings of antipathetic animals, mutilation and illness' (Baratay and Hardouin-Fugier 220, 221). The welfare of zoo animals became the contested terrain of both zoos and their opponents, with the victory of the professionals certified by the 'normality', health, procreation and longevity of the animals, a demonstration of their expertise.

With the moral criteria thus delimited, the priesthood of wildlife stewards could expand their meticulous pastoral power, caring (in species-specific terms) for every need of the animal - dietary, territorial, social, behavioural and sexualexercising total management of their lives, from birth and prior to death and beyond. As Hediger wrote, 'the animals in a modern zoo require a thousand and one small, seemingly insignificant attentions and we must constantly strive 
to discover their needs' ('From Cage to Territory' 17). In such highly detailed and individualised natural nurture, the 'pastoral power' described by Foucault as the forerunner of modern biopolitics is returned to its roots in the political economy of human care for animals (Security). The telos of this administration of love is achieved in the classic pastoral image of peaceful naturalism that zoos present: that of contented animals grazing and playing in well-replicated habitats.

This pastoral regime, devoted to the flourishing of all and each, sought to enact the biblical utopia of Eden (or its messianic repetition which imagines the peaceful coexistence of wolves and lambs). Of course, this zoo regime is in many ways unnatural. Zoos do not simply imitate nature, attempting a perfect simulacrum, but rather improve it, offering their wards a blessed life free of the harsh realities of the wild. Indeed, central to Hediger's philosophy was not only the assertion that zoos could effectively mimic wild habitats such that the animals were no worse off (the famous equation of cage with territory); rather, as if needing to compensate for a lack he did not admit they had, Hediger insisted that animals in captivity lived lives superior to those of their wild counterparts (Wild). Zoo animals are provided with food without needing to forage or hunt, or even compete. They are protected from exposure to the elements and from predation. They receive medical care to prevent and cure injury and disease. They are unburdened by stress and trained to perform natural behaviours. Demanding only the sacrifice of freedom, the zoo is an apparatus for the production of paradise.

It is, of course, an imperfectly functioning machine, often defective. The lack of real space or aleatory events; the omnipresence of the 'super-alpha' human managers and spectators; the separation from natural forms of lifethese and many other elements of zoo forgery interrupt and complicate the intended administration of love and replication of nature. The stories with which we opened demonstrate the iatrogenic confusion-that produced by the uneffaceable presence of the caretakers - that accompanies assisted reproduction. Improving the techniques of zookeeping and captive breeding has required numerous errors over repeated experiments, the burden of which falls always on the animal targets.

But even the perfect functioning of the Eden-machine only enacts its utopia through the disavowal of mortality. Precisely insofar as zoos are biopolitical institutions devoted to the production and nurture of life, they disturb and ignore the role of death. As Boria Sax has argued, zoos perform the Eden myth in protecting their animals from natural threats such as starvation, disease and especially predation. They attempt to exclude death from their domain, and display an image of nature from which the sustaining death of predation and even the natural death of old age and disease are entirely excluded. This is 
of course an impossible and even hypocritical task; for carnivorous animals, death is inherent in their feeding regimens; it is a matter to be forestalled, allowed, or even created by zoos' veterinary professionals. And as we will see, the way in which death should be managed - when and how animals should be allowed, and even made to die - is an inescapable quandary for this biopolitical apparatus.

The latter third of the twentieth century saw zoos align themselves with the growing environmental movement. Taking on the righteous mantle of endangered species preservation, they sought to be known as wildlife parks, arks amid the deluge of habitat destruction and the concomitant decline of animal populations. Amid the scientific and colonial discourses of extinction devoted to the enunciation of absences (de Vos), zoos transformed from heterotopias of consolation to crisis (Foucault, 'Of Other Spaces' 24), carving out their own moral niche as protectors (and exhibitors) of threatened creatures. For Baudrillard, this is just one more step in an 'uninterrupted process of annexation through extermination, which consists of liquidation, then of making the extinct species speak, of making them present the confession of their disappearance' (136). Zoos developed ties with other Western elites who formed the global network working towards conservation, a regime of scientific management that can be understood as 'ecological governmentality' or 'environmentality' (Darier). This biopolitical apparatus conducted in tandem the 'two poles around which the organisation of power over life was deployed', that is, '[t]he disciplines of the body and the regulations of the population' (Foucault, Will 139), but applied not to human societies but to the entirety of nonhuman biological life. Sampled, regulated, harvested, managed, animals were targeted through a range of technologies, both broadly and finely calibrated, both insitu and ex situ.

It was this latter, controversial form of 'off site' conservation, severed from the connectivities of place, that zoos put forward as their own essential contribution to the war against extinction. 'If zoos did not exist,' writes Colin Tudge, 'then any sensible conservation policy would lead inevitably to their creation' (243; see also Luoma). For many others, captive breeding remains an impoverished alternative to habitat protection, which even if it is itself contested, and implicated in struggles over nation, gender, class and other questions of human identity (Herda-Rapp and Goedeke; Lowe), is considered both economically and ecologically superior as a means to protect wildlife (Bowkett; Donahue and Trump; Lee, Zoos 94-99; Mazur; Norton et al.; Price and Fa; Snyder et al.). But even if, as Hancocks argues, zoos 'are not the best places for holding and breeding rare species' (xv) due to the conflicting demands of public exhibition, wildlife conservation has nonetheless come to be articulated as their highest priority, thereby transforming the institution and its techniques of animal 
management. The expertise in captive breeding that zoos had developed, under the economic incentive created by greater restrictions on the capture and importation of wildlife, could be put to use in service of the conservationist goals they now expounded.

Sexual reproduction - as the meeting point of the population and the bodywas the central element for intervention, particularly in the form of breeding programmes directed towards self-sustaining populations in zoos (i.e. maintaining the supply of animals for display (Donahue and Trump 77; Margodt 13)), as well as eventual reintroduction to the wild. The genetic diversity and demographic health of captive animal populations has long been monitored through tools such as studbooks and other international records. More recently, Species Survival Plans (whose original revealing title was 'master breeding plans') have guided the breeding exchanges of endangered species according to criteria of genetic diversity and sustainable population size and makeup. With the development of molecular biology, genetic engineering and biotechnology, established approaches to animal husbandry were enhanced by the latest technoscientific techniques such as artificial insemination, in vitro fertilisation, embryo transfer and intergenic surrogacy. Animal studies scholars have assessed the impact on animals of new genetic technologies used in laboratory experimentation (Haraway, Modest_Witness), pet replacement (McHugh), livestock farming and meat production (Franklin; Twine) and art practice (Gigliotti). Yet while in those contexts experimental, sentimental, economic and aesthetic factors have shaped animal genomes, in conservation biology and captive breeding it is the genetic diversity of endangered species that is problematised as an object of knowledge and intervention. Ultimately, cloning has been pursued as a means to rejuvenate threatened species (such as the gaur and the African wildcat) or even to resurrect the extinct (Corley-Smith and Brandhorst; Lanza et al.; Lee, 'Can Cloning?'). ${ }^{3}$

The 'population' on which this biopolitics of endangered species preservation intervenes is, in this case, not any actual group of cohabiting animals. Rather, they reside in disparate sites throughout a region or even the world, and their capacity to interbreed only exists as the result of human efforts to design their interactions and to transport individuals or substances extracted from their bodies. Nonetheless, via the discourse of the 'postvital' life sciences of genetics and molecular biology, the somewhat nebulous object of 'species' is provided with a remarkable coherence and efficacy as 'life' (and its extinction and protection) is relocated to the virtual zone of information. Richard Doyle argues that the discourse of molecular biology offers 'a technoscientific power that works by producing an invisibility of the body, whose object is no longer the

3 Indeed the halo of the conservation imperative is such that, even in the midst of a determined critique of biotechnology, Steven Best pauses to concede that 'cloning may prove a valuable tool in preserving what can be salvaged from the current extinction crisis' (13). 
living organism. It is instead an object beyond living - ready to live, beyond the finitude of an organism and its ongoing interactions with and constructions of an environment' (59). In this 'informatic essentialism' (Thacker) or 'biocybernetics' (Mitchell), embodied and emplaced beings are decontextualised and conceived as calculable and controllable genetic information.

The archives of cryopreserved genetic material known as 'frozen zoos' or genome banks (Corley-Smith and Brandhorst; Lanza et al.) might be seen as the ultimate abstraction, the effective enactment of a genetic utopia seeking to arrest time and halt or reverse extinction, confident of the redemptive power of technological intervention. Described by Soulé as 'suspended ex situ programs' in which 'living material is metabolically slowed or arrested' (Soulé 748), they exemplify in extremis the zoo-logic by which embodied living creatures, in connectivity with generations and kin, and emplaced within habitat, are subordinated to reified notions of the species and its genome. Stewart argues that the Ark is 'the archetypal collection ... a world which is representative yet which erases its context of origin' (152). These archives repeat the displacement that the zoo effects in relation to the wild, bringing about its ultimate 'forgetting.' While this fetishist strand of biology is mostly only proposed as a backup to conservation efforts, an emergency archive banking frozen information against the likelihood of species extinction, what it reveals is the hierarchy of differential valuation that structures the biopolitics of endangered species preservation, prioritising species over individuals, code over life, genes over bodies.

Yet being aware of how biological knowledge now perceives animals as strings of DNA code does not quite 'accord us a diagram of power' (Doyle 59) whose operation we can detect and contest. This epistemic change does not replace but only modifies the existing disciplinary zoo-power that makes visible (or otherwise) its collection of animal bodies. We must recognise that while, as Doyle puts it, the biological gaze of these 'postvital' life sciences 'does not see bodies; it sees only sequences, genomes', it nonetheless 'requires' bodies for its operation (131, emphasis added). As the means by which to manipulate the immaterial object of knowledge that is the genetic species body, the living bodies of animals, 'invisible' to the molecular biopolitics of the population, remain the ever more starkly visible objects of power's intervention. Members of endangered species are subjected to an increasingly intensive anatomo-politics of the animal body: regular testing, extraction of fluids, transportation, enforced tranquilisation, separation and recombination of social groups, imposed breeding and the removal of offspring ... that is, veritable abduction and rape at the hands of their shepherds, with all the supposedly humorous sexual confusion this generates. Such is the nature of love at the zoo. The closer a species to extinction-when a wild population is most endangered, or a captive one most fragmented, when the category of 'species' holds the most importance and thus the visibility of 
living organisms within the whole ensemble is most obscured - the stronger then is the grip in which the bodies of the last remaining individual animals are held. ${ }^{4}$

Thus the secular shepherds of planetary life assembled an apparatus of scientific power/knowledge over their animal wards. As the ecological crisis grew, the schema of zoo as Eden was soon replaced by that of the Ark. If the former offered its animal charges leisure and security over inhospitable wilderness, the latter offered refuge from apocalyptic destruction. Their human visitors were now also their rescuers; to communion was added redemption.

Of course, the unprecedented wave of extinction that this apparatus is deployed to combat is a very real and urgent state of affairs. Deborah Bird Rose works with the powerful notion of double death in witnessing to the destructive effects of colonialism and development (Reports). Modern industrial capitalist societies have broken the social and ecological connections that sustain generations, thus disabling the ability of country to replenish itself, to maintain resilience. The lives of those passed away are prevented from shaping and nurturing the future they handed down; the dead, whose voices should guide the living, are doubly silenced. In further exploring this notion in relation to the natural world, Rose articulates and affirms the ecological and evolutionary sense in which death is immanent and necessary to life ('What If?'). This natural process is different in kind from the doubly effective mass death of modern societies, 'the amplification of death, so that the balance between life and death is overrun' ('What If?' 75; see also Reports 7, 26-7, 34-6, 175-6; and Wild). Here death is no longer part of the self-perpetuation of life, but also wounds the regenerative capacity of ecosystems, thus threatening to exhaust the very potential of generation. If extinction, too, has been an immanent part of the evolutionary process, the rate and scale of contemporary 'man-made' extinction is the definitive double death: the irreparable loss not only of the living but of the multiplicity of forms of life.

It is against this double death of species extinction in the wild that these zoo programmes and interventions are directed. They are not innately violent or destructive, but rather biopolitical forms of power given over to the production and nurture of species life. But for all that they would banish death from their domain, this utopian goal is impossible, and they are forced to maintain their own complex relation to animal death. Indeed, in their managerial ignorance of the connectivities that sustain forms of life, they botch their goal of loving protection, producing creatures only to abandon them to injury and death.

4 In some cases, it is not the most precious individuals of the endangered species but rather their 'genetically inferior' kin (Lanza et al. 84-86) or even disposable surrogates from related, but more common and thus less valuable, species that are utilised in breeding and reintroduction programmes. 
Though difficulties and confusions still abound in the attempts of this nonhuman scientia sexualis to manage the procreation of captive animals, many ex situ breeding programmes have been extremely successful. The tragic irony is that this increased capacity to make live leads directly to deaths, either accepted as inevitable or even at times directly imposed. Given the persistence of habitat destruction, the result of this expertise in assisted reproduction is a population that exceeds the accepted sphere of zoological care-certain animals here become either an unwanted surplus or an experimental loss. In the interests of perpetuating a species, the lives of numerous individuals are consigned to genetic irrelevance or collateral damage, tossed overboard the ark.

Surplus populations have often been an issue for the circumscribed spatial and economic resources of zoological gardens. Largely, such redundancies have been quietly dealt with by zoo professionals protective of their domain of expertise and authority. But their own much-publicised principles of preservation and care have not only exacerbated this problem - in successfully breeding more animals than they can manage - but also exposed the hypocrisy of their solutions. The public furore over the euthanasia of a number of healthy Siberian Tigers in Detroit perfectly highlights the biopolitical contradictions generated by captive breeding. As detailed by Donahue and Trump (119-125; see also Norton et al. 187-208), the decision to end the lives of these animals, who were neither old nor ailing but simply genetically unfit for the purposes of the Species Survival Plan, brought significant media and legal attention to the nature of zoological power over nonhuman animal life. While zoos attempted to defend such decisions in terms of the 'carrying capacity' of the ark- as necessary sacrifices in an overarching salvific effort - such justifications were undermined by the zoos' own supposed core principle of care for life.

Such sovereign decisions over life and death made by scientist-managers demonstrate that the zoo, like the hospital, 'delimits a space of exception in which a purely bare life, entirely controlled by man and his technology, appears' (Agamben, Homo Sacer 164). While not a camp entirely devoted to death, its exhibition and production of life generates its own contradictory thanatopolitics. The responsibility and burden rests entirely with the zoo apparatus: these lives only exist in the first place through its programmes of assisted reproduction. Moreover, this rational violence is compounded by the absence of any question of viability: a sovereign decision is made to 'put down' completely healthy creatures simply because they are not considered to contribute to the genetic future of their own species. Not only are the physical bodies of the excluded considered to be surplus to the genetic body that is the preservationists' real target; their very existence is seen as competing with their own species' survival, for space on the ark and indeed within the genome. This 
is no longer a paradise for each and all but a cut-throat business: 'In a world of finite resources for captive breeding, culling one animal directly allows another to live' (Norton et al. 189).

The irony of Species Survival Plans requiring the products of their own breeding programmes to be put to death is reduced somewhat if one considers that (as has often been charged) these self-serving plans are mostly concerned with the sustainability of captive populations for display. Yet where bona fide reintroduction schemes do exist, death is once again a prominent effect of biopolitical intervention. Here, however, it is not the direct result of a managerial decision, but simply the outcome of putting into practice the aims of reintroduction to the wild.

It has often been claimed that zoo animals are not wild creatures at all but artifacts of the zoological institution (Lee, Zoos). Yet such philosophical critiques are too often so concerned with refusing the category of wildness to animals tainted by contact with a seemingly omnipotent humanity that they fail to delineate the precise nature and extent of this anthropogenic influence. On the other hand, zookeepers and conservation biologists are often for their part well aware of the behavioural and genetic impacts of captivity and devote their knowledge and expertise to understanding and mitigating such adaptations. However, as Marc Bekoff protests, ethical responsibilities to individual animals are commonly ignored within conservationist practices that assume a moral mandate to redesign nature.

The survival rates of reintroduced captives provide a sad demonstration of the 'docile bodies' that zoos produce. Jule et al. found that captive-born carnivores were significantly less likely to survive reintroduction than those translocated from the 'wild', being 'particularly susceptible to starvation, unsuccessful predator/competitor avoidance and disease' (1). One study of golden lion tamarins reported that ' $60 \%$ are lost in the first post-release year', and such poor success rates are typical. It is an indication of persistent genetic reductionism that it takes such a fatal demonstration of the inability of captive-born animals to negotiate their 'native habitats' for these scientists to conclude that (rather than simply genetically ingrained) 'many survival-critical behaviours may be learned' (Beck et al. 7). Clearly, however, they are not learned in captivity; thus "deficiencies" from the viewpoint of reintroduction to the wild ... also reflect successful adaptations to captive environments' (Beck et al. 7). Thus it is that animals accustomed to the distorting 'Eden' zoos attempt to providefree of disease, predation, hunger and danger-find themselves 'returned' to thoroughly unfamiliar and dangerous environments. The would-be paradisiacal exclusion of predation from zoos, when discarded in favour of reintroduction to the 'wild', abandons to suffering and death the naive animals it has long housed and nurtured. 
As animal behaviourists have pointed out, such regimes of management, in their focus on population and genetics, ignore an essential element relevant to survival, failing to recognise the importance of learned behaviours, skills and knowledge and the extent to which the capacities needed for survival decline in captivity - what Margodt calls a 'behavioural bottleneck' (19). As Nicole Mazur puts it, 'Essentially, the physiological, psychological and environmental needs of the Ark's passengers have not been catered for' (49). Even where behaviour has recently come to be seen as an important part of conservation biology's calculations and an aid in extending the survival of reintroduced species (Blumstein and Fernández-Juricic), this in many ways merely expands the knowledge and proficiency available to wildlife management, without allowing its awareness of animal subjectivity to challenge the very principles of such attempts to remake nature. Efforts are made to prepare animals for reintroduction by programming wildness within the zoo, by mimicking (or 'priming' for) predation, disease, competition, foraging, and by training the animals in 'survival skills' lost in captivity (Griffin et al. 2000). Yet there are limits to how far such behavioural losses can be compensated for through enrichment. And ultimately - given that the goal of this biopolitics is the propagation and survival of these species - it is the 'wild' that is eventually transformed into an extension of the zoo, such as when strategies of 'soft-release' provide animals with intense support after reintroduction through in situ provisioning and medical care, in effect disciplining the wild (Rinfret).

The biopolitics of endangered species preservation thus not only produces a 'bare life' whose genetic unsuitability exposes it to death; it also produces, if not quite any longer the living dead witnessed from Nietzsche to Berger, a wounded life severed from the connectivities of emplaced kin and habitat, from the traditions of behaviour learned and adapted within such forms of life across innumerable generations. Though itself directed against the double death of extinction, captive breeding robs the dead of their ability to sustain present lives with the gift of their wisdom. As Rose writes, in terms just as applicable to nonhumans as humans, 'Flourishing life is evidence of current and ancestral labour, but it all can come undone when the organisation fails' (Reports 173). The intense focus of zoological programmes on the propagation of life and the survival of future generations disguises the extent to which their methods of intervention - artificially and inadequately focused on the genetic, species body - are themselves attacks on the ability of life to reproduce itself as resilient and self-sustaining. Efforts at reintroduction show that zoos wound the capacity of life to gift future generations an existence that can flourish, at least in the 'wild' - which puts into doubt the very value of that goal for populations in captivity.

The contemporary biopolitics of zoological care, revolutionised by Hediger and since developed in all manner of enrichments and interventions, may have 
reduced the incidence of stereotypy and other effects of captivity; but it has a long way to go to truly heal the wounds of the 'sickly beasts' procured and produced by zoos. Our time is faced with an enormous question of love and responsibility; in a world of doubled death, where the activities of civilisation have so disrupted the connectivities and regenerative capacities of nonhuman life that irreparable extinctions have multiplied, we must do all we can to ameliorate this situation. But it is a strange and harsh apparatus of love that, in perverse mimicry of the nature it has extinguished, exposes to confusion, suffering and death the very endangered creatures that it breeds.

Matthew Chrulew is a Postdoctoral Research Fellow in the Centre for Research on Social Inclusion, Macquarie University. He has written numerous journal articles at the intersection of critical theory and animal studies. Currently he is writing the volume Mammoth for Reaktion Books, and editing (with Dinesh Wadiwel) the collection Foucault and Animals.

\section{Works Cited}

'Animal Behavior: Love at the Zoo.' Time, 24 May 1968. <http:/www.time.com/ time/magazine/article/0,9171,844461,00.html> Accessed 29 Nov. 2009.

Adorno, Theodor W. Minima Moralia: Reflections from Damaged Life. Trans. E. F. N. Jephcott. London: New Left Books, 1974.

Agamben, Giorgio. Homo Sacer: Sovereign Power and Bare Life. Trans. Daniel Heller-Roazen. Stanford, CA: Stanford UP, 1998.

- The Open: Man and Animal. Trans. Kevin Attell. Stanford, CA: Stanford UP, 2004.

Baratay, Eric, and Elisabeth Hardouin-Fugier. Zoo: A History of Zoological Gardens in the West. Trans. Oliver Welsh. London: Reaktion Books, 2002.

Baudrillard, Jean. Simulacra and Simulation. Ann Arbor: U of Michigan P, 1994.

Beck, Benjamin B., Devra G. Kleiman, M. Ines Castro, Jon Ballou and Tara Stoinski. 'Behavioural deficiencies in reintroduced golden lion tamarins are clues to the effects of successful adaptation to the zoo environment.' Advances in Ethology 33 (1998): 7-8.

Bekoff, Marc. 'The importance of ethics in conservation biology: let's be ethicists not ostriches.' Endangered Species Update 19.2 (2002): 23-6. 
Berger, John. 'Why Look at Animals?' About Looking. London: Writers and Readers Publishing Cooperative, 1980. 1-26.

Best, Steven. 'Genetic Science, Animal Exploitation, and the Challenge for Democracy.' Leonardo's Choice: Genetic Technologies and Animals. Ed. Carol Gigliotti. Dordrecht: Springer, 2009. 3-19.

Blumstein, Daniel T., and Esteban Fernández-Juricic. A Primer of Conservation Behaviour. Sunderland, MA: Sinauer Associates, 2010.

Bowkett, Andrew E. 'Recent Captive-Breeding Proposals and the Return of the Ark Concept to Global Species Conservation.' Conservation Biology 23.3 (2009): 773-776.

Chrulew, Matthew. 'From Zoo to Zoöpolis: Effectively Enacting Eden.' Metamorphoses of the Zoo: Animal Encounter after Noah. Ed. Ralph R. Acampora. Lanham: Lexington Books, 2010. 193-219.

Corley-Smith, Graham E., and Bruce P. Brandhorst. 'Preservation of Endangered Species and Populations: A Role for Genome Banking, Somatic Cell Cloning, and Androgenesis?' Molecular Reproduction and Development 53 (1999): 363 67.

Darier, Éric, ed. Discourses of the Environment. Oxford: Blackwell, 1999.

De Vos, Ricardo. 'Extinction Stories: Performing Absence(s).' Knowing Animals. Ed. Laurence Simmons and Philip Armstrong. Leiden: Brill, 2007. 183-195.

Donahue, Jesse, and Erik Trump. The Politics of Zoos: Exotic Animals and their Protectors. DeKalb: Northern Illinois UP, 2006.

Doyle, Richard. On Beyond Living: Rhetorical Transformations of the Life Sciences. Stanford, CA: Stanford UP, 1997.

Esposito, Roberto. Bios: Biopolitics and Philosophy. Trans. Timothy Campbell. Minneapolis: U of Minnesota P, 2008.

Foucault, Michel. 'Of Other Spaces.' Diacritics 16 (1986): 22-27.

- Security, Territory, Population: Lectures at the Collège de France, 1977-78. Trans. Graham Burchell. Ed. Michel Senellart. London: Palgrave Macmillan, 2007.

-. Society Must be Defended: Lectures at the Collège de France, 1975-76. Trans. David Macey. Ed. Mauro Bertani \& Alessandro Fontana. London: Penguin Books, 2004. 
Link, Theodore. 'Zoölogical Gardens, a Critical Essay.' The American Naturalist 17.12 (1883): 1225-29.

Lowe, Celia. Wild Profusion: Biodiversity Conservation in an Indonesian Archipelago. Princeton: Princeton UP, 2006.

Luke, Timothy W. Ecocritique: Contesting the Politics of Nature, Economy, and Culture. Minneapolis: U of Minnesota P, 1997.

Luoma, Jon R. A Crowded Ark. Boston: Houghton Mifflin, 1987.

Margodt, Koen. 'Zoos as Welfare Arks? Reflections on an Ethical Course for Zoos.' Metamorphoses of the Zoo: Animal Encounter after Noah. Ed. Ralph R. Acampora. Lanham, MD: Lexington Books, 2010. 11-36.

Mazur, Nicole A. After the Ark? Environmental Policy Making and the Zoo. Carlton South, Vic.: Melbourne UP, 2001.

McHugh, Susan. 'Bitches from Brazil: Cloning and Owning Dogs through The Missyplicity Project.' Representing Animals. Ed. Nigel Rothfels. Bloomington: Indiana UP, 2002. 180-98.

Mitchell, W. J. T. 'The work of art in the age of biocybernetic reproduction.' Modernism/Modernity 10.3 (2003): 481-500.

Nietzsche, Friedrich. Twilight of the Idols and The Anti-Christ. Trans. R. J. Hollingdale. London: Penguin Books, 1990.

Norton, Bryan G., Michael Hutchins, Elizabeth F. Stevens and Terry L. Maple, eds. Ethics on the Ark: Zoos, Animal Welfare, and Wildlife Conservation. Washington: Smithsonian Institution, 1995.

Ojakangas, Mika. 'Impossible Dialogue on Bio-Power: Agamben and Foucault.' Foucault Studies 2 (2005): 5-28.

Price, Mark R. Stanley, and John E. Fa, 'Reintroductions from Zoos: A Conservation Guiding Light or a Shooting Star?' Zoos in the 21st Century: Catalysts for Conservation? Ed. Alexandra Zimmermann, Matthew Hatchwell, Lesley Dickie and Chris West. Cambridge: Cambridge UP, 2007. 155-77.

Rinfret, Sara. 'Controlling Animals: Power, Foucault, and Species Management.' Society and Natural Resources 22 (2009): 571-578.

Rose, Nikolas. The Politics of Life Itself: Biomedicine, Power, and Subjectivity in the Twenty-First Century. Princeton: Princeton UP, 2007.

Rose, Deborah Bird. Reports from a Wild Country: Ethics for Decolonisation. Sydney: U of New South Wales P, 2004. 
- The Will to Knowledge. Trans. Robert Hurley. 3 vols. Vol. 1, The History of Sexuality. London: Penguin Books, 1998.

Franklin, Sarah. Dolly Mixtures: The Remaking of Genealogy. Durham: Duke UP, 2007.

Gigliotti, Carol, ed. Leonardo's Choice: Genetic Technologies and Animals. Dordrecht: Springer, 2009.

Griffin, Andrea S., Daniel T. Blumstein, and Christopher S. Evans. 'Training Captive-Bred or Translocated Animals to Avoid Predators.' Conservation Biology 14.5 (2000): 1317-1326.

Gruffudd, Pyrs. 'Biological Cultivation: Lubetkin's Modernism at London Zoo in the 1930s.' Animal Spaces, Beastly Places: New Geographies of HumanAnimal Relations. Ed. Chris Philo and Chris Wilbert. London: Routledge, 2000. 222-42.

Haraway, Donna J. Modest_Witness@Second_Millennium.FemaleMan $\mathbb{C} \_M e e t s \_$ OncoMouse ${ }^{\mathrm{TM}}$ : Feminism and Technoscience. New York: Routledge, 1997.

—. When Species Meet. Minneapolis: U of Minnesota P, 2008.

Hardt, Michael, and Antonio Negri. Empire. Cambridge, MA: Harvard UP, 2000.

Hediger, Heini. Wild Animals in Captivity: An Outline of the Biology of Zoological Gardens. Trans. G. Sircom. New York: Dover, 1964.

- Report on Taronga Park Zoo from the Viewpoint of Biology of Zoological Gardens. Sydney: Government Printer, 1966.

- 'From Cage to Territory.' The World of Zoos: A Survey and Gazetteer. Ed. Rosl Kirchshofer. Trans. Hilda Morris. London: Batsford, 1968. 9-20.

Herda-Rapp, Ann, and Theresa L. Goedeke, eds. Mad about Wildlife: Looking at Social Conflict over Wildlife. Leiden: Brill, 2005.

Jule, Kristen R., Lisa A. Leaver and Stephen E.G. Lea. 'The effects of captive experience on reintroduction survival in carnivores: A review and analysis.' Biological Conservation 141.2 (2008): 355-363.

Lanza, Robert P., Betsy L. Dresser and Philip Damiani. 'Cloning Noah's Ark.' Scientific American, 19 November 2000: 84-9.

Lee, Keekok. Zoos: A Philosophical Tour. Basingstoke: Palgrave Macmillan, 2005.

Lee, Kenneth. 'Can Cloning Save Endangered Species?' Current Biology 11.7 (2001): R245-6. 
-. 'What If the Angel of History Were a Dog?' Cultural Studies Review 12.1 (2006): 67-78.

- Wild Dog Dreaming: Love and Extinction. Charlottesville: U of Virginia P, 2011 .

Rothfels, Nigel. Savages and Beasts: The Birth of the Modern Zoo. Baltimore: Johns Hopkins UP, 2002.

Sax, Boria. 'Are There Predators in Paradise?' Terra Nova 2.1 (1997): 59-68.

Shukin, Nicole. Animal Capital: Rendering Life in Biopolitical Times. Minneapolis: U of Minnesota P, 2009.

Snyder, Noel F. R., Scott R. Derrickson, Steven R. Beissinger, James W. Wiley, Thomas B. Smith, William D. Toone and Brian Miller. 'Limitations of Captive Breeding in Endangered Species Recovery.' Conservation Biology 10.2 (1996): 338-348.

Soulé, Michael E. 'Conservation: Tactics for a Constant Crisis.' Science 253 (1991): 744-50.

Stewart, Susan. On Longing: Narratives of the Miniature, the Gigantic, the Souvenir, the Collection. Baltimore: Johns Hopkins UP, 1984.

Thacker, Eugene. 'Data Made Flesh: Biotechnology and the Discourse of the Posthuman.' Cultural Critique 53 (2003): 72-97.

Tudge, Colin. Last Animals at the Zoo: How Mass Extinction Can Be Stopped. Oxford: Oxford UP, 1992.

Twine, Richard. Animals as Biotechnology: Ethics, Sustainability and Critical Animal Studies. London: Earthscan, 2010. 